\title{
"Urbanisation of the Steppe". Sedentarization, Mobility, and Collective Business-Making Among the Torghuts in Post-transitional Mongolia
}

\begin{abstract}
Drawing from Danuta Markowska’s notion of "urbanisation of the steppe" (1969) I present in this article some processes of transformation of pastoral life that occurred in postsocialist and posttransitional Mongolia. I focus especially on how some new forms of sedentarization, mobility and self-organization appeared among the new generation of the Torghuts from Bulgan district (soum) in western Mongolia, sons and daughters of the herders. Nowadays, they are developing their new businesses in Bulgan, and also in Ulaanbaatar, the capital city, where they have established a Torghut business-hub called the Torguud Town. In this article I will reconstruct some essential processes in which they rearrange their space of living and their patterns of mobility, and show that these reactions, the new patterns of sedentarization and mobility, are related to spatial dimensions of pastoral self-organization. Moreover, these reactions are still rooted in mobility, constant swapping and a "technology of solidarity", and thus embody very specific pastoral practices and ideas.
\end{abstract}

Keywords: cooperation, mobility, sedentarization, Mongolia, self-organization, business, the Torghuts

It is not an easy task to answer intuitively the question of what the notion of "urbanisation of the steppe" coined by a Polish sociologist Danuta Markowska at the end of the sixties, may mean. Basically, it is a sort of elaboration on a possible transition, that may have had happened in the Mongolian People's Republic, a move from the position of copying with nature, the surrounding natural harsh conditions, e.g. windy and freezing steppes, to the position of copying with other 
human fellows, like other pastoralists, craftsmen, teachers or clerks. To a certain extent this may resemble the desired Marxist approach, leading from the realm of necessity to the realm of freedom and, to use the famous Engelsian phrase, therefore making the "leap to the kingdom of freedom" (see: Walicki 1995). As Markowska put it in her article from the year 1969 (Markowska 1969), it is first of all about making work societal, and creating the dominance of the socially shared production; the measure of urbanisation is thus the degree to which it stands for a move form autonomous, 'private' labour, to a sort of social one. It is then about understanding this latter, social kind of labour, considered as an action in which people are delivering the fruits of their work first of all to their peers, and not to the surrounding environment, and an action in which their needs are met more in relationships with other people, and not with nature itself (Markowska 1969: 40) Furthermore, in Mongolia, as she argued, this struggle for urbanisation is a case in which making work social is preceding technical or techno-economical change.

Certainly, one could hypothesise them if that kind of understanding was also a result of the collaboration taken on by Polish and Mongolian governments in the post-Stalinist period. There was a series of Polish and Mongolian extensive research, launched in the $60 \mathrm{~s}$, in which the scientific exchange was meant to support the processes of communist modernisation, urbanisation, and industrialisation, that could be used later in transforming the vast, windy steppes and pasturelands in Mongolia according to the Soviet version of "the big push" and the Soviet, "leap into modernity" (Leszczyński 2013). Thus the research on the "urbanisation of the steppe" was dedicated to the future policy of Mongolian modernisation, and to an unprecedented moment of social change over the 50 and 60s when animal husbandry was subjugated to widespread collectivisation, carried out in Mongolia by creating cooperative state-owned pastoralist farms called negdels. However, the language of the research is reminiscent of scientific propaganda that suggests the Soviet model of modernisation as the best and the proper one. But on the other hand, this may also be theorised akin to the proposed the 'heteronymous shift' of late socialism as put forward by Alexei Yurchak. ${ }^{1}$ According to Yurchak, building the socialist state in Russia at a certain moment brought about a sort of shift from a "semantic" to "pragmatic" model of ideological involvement. Over this late way of building socialism, he claims, especially on the ground, it became predominantly "a constitutive of everyday life", and "implied a more complex and shifting relationship to Soviet ideological form", implicitly "decoupling" from the strict Soviet ideals (Yurchak 2003: 481). I would like to follow this thought while being aware of the many differing contexts in interpreting the cases of Soviet-like collectivisations, often related to terror and violence (in Mongolia this included acts of murdering many Buddhist monks, in the previous period counted up to $44 \%$ of male population). However, I would like to claim that the Mongolian pas-

I owe this interpretation to the brilliant argument made by Agnieszka Halemba in regard to the new function of the institution of House of Culture in Kosh-Agach, Altay (see: Halemba 2011). 
toralists and local leaders (dargas) of the soums also, and similar to late socialist Soviet citizens, "reinterpreted the meanings of the ideological symbols, [thus] deideologising static dogmas and rendering communist values meaningful on their own terms". In this way, I would like to focus on the story in which the herders got through the communist modernisation "on their own terms", exactly as that was revealed across the country by the researchers who conducted their studies over the 60s and 70s, such as Danuta Markowska, Sławoj Szynkiewicz, and other Polish and Mongolian scientists. Having said that, to a certain degree I follow the detailed descriptions of the change of that time in the texts like The Urbanization of the steppe which sheds light on the period and processes in a particular, intriguing way.

In this sense, I follow the massive processes of transformation of pastoral life that occurred in postsocialist and post-transitional Mongolia. What was quite characteristic for the negdelization of the 60s, as Markowska pointed out, was a relatively distinct process of socialist "urbanisation". First, the so-called "working class" in Mongolia was relatively numbered only a dozen or so thousand. But second, a sort of relevancy of the newly created herders brigades and the closely collaborating teams of families (yurts) appeared, and the so-called khot ails soon became basic units of the for the organisation of the cooperative farms and their brigades. Therefore, what is especially important here, this Mongolian kind of "urbanisation" was related to a certain pastoral system of sharing labour, exchanging work and favors, and the constant celebration of this in the subsequent feasts and meetings (Szynkiewicz 1981; Sneath 2006). In fact, this was also directly related to the narrow "alimentation basis" of the herders, in regard to the tools and commodities they owned. This significantly poor range and quantity of material goods was precisely counted by Danuta Markowska on the basis of administration reports: in relation to other possessed goods in the households, tools and consumer goods covered from 3\% to 8\% of the overall family budgets (Markowska 1969:33). On the one hand, this is certainly the result of nomadic mobility and the limitation of possessions stemming from the necessity of transporting the goods, yurts and other facilities, on the backs of camels and horses. Besides, this kind of practicing mobility is certainly also related to keeping and storing small but valuable objects, such as silver dishes (usually decorated-coined silver bowls) or jasper snuff-boxes, previously bought and brought from monastery centers, which were providing for herders the highly artful and sacred craft objects. But on the other hand, this was also, and probably first of all, related to a sort of a whole "socio-technical system" (Sneath 2003, a notion borrowed form Bryan Pfaffenberger, Pfaffenberger 1992), that was consisting of diverse modes of mobility and temporary sedentarization of the herders and their flocks: basically, it was based on constant "adapting" or "adjusting" to the capacity of pastures, to the kinds of grass and animal biology, to the veterinary techniques, and also to social capacities, transportation, meteorology and many other fields (including ritualistic and symbolic practices). 
I focus especially on that later issue here, considering the case of the newly created patterns of mobility, self-organisation and sedentarization that appeared among the new generation of Torghut nomads from Bulgan district (soum) in western Mongolia, located on the southern slopes of Altai, well known for their fast-moving with animals while changing their seasonal pasture camps. As it turns out nowadays, they are developing their new trade-businesses in the soum of Bulgan, across the border with Xinjiang, and also in Ulaanbaatar, in the capital city, where they established a Torghut "business-hub" informally called Torguud Town. In this article, I focus on the way in which they rearrange their skills of moving and temporary settling down, and how they reproduce at the same time the originally pastoral "socio-technical system" of mobility considered also as a very thrifty response to the socioeconomic change they experience. Thus I draw on various forms of "urbanisation of the steppe" that happened almost a half of century later in Mongolia and appeared at least among a new generation of the Torghuts, sons and daughters of the herders from Bulgan. I will take a closer look at how they create new economic networks, how they operate according to their former, pastoral idioms of cooperation, and about how they created a system of swap and exchange urban environment, thus creating their post-pastoral ways of navigating collective endeavours.

However, what I am aiming at is not to depict any linear process of urbanisation or modernization in this case, nor suggesting a possible, complete form of it. Thus I go in line with the earlier argument coined by Manduhai Buyandelgeriyn (2008) on understanding transition as anthropologically unpredictable, and therefore expressed in the notion of the 'post-post-transitional' view, with the double loop of the prefix "post-" (Buyandelgeriyn 2008: 237). Nevertheless, I would argue that the process of Mongolian transformation has already its history, so this article is also about a certain post-transitional moment of the process of change that began in the 90s, and after the recent three decades seem to slowly move towards the past, thus creating something that French historians would call "immediate history" (histoire immédiat), a history that is almost still ongoing (Paczkowski 2014). Moreover, I am using the notion of the "urbanisation of the steppe" here precisely in order to sustain all its complexity and its potential to render the emerging social realms in contemporary Mongolia, still created anew, with its quite unpredictable dynamic. In this sense it is rather a depiction of a process that is embedded in the emerging forms of capitalism (see: e.g. Bumochir, Plueckhahn 2018) and a sort of vernacular business-making, and I would call them post-transitional as means that a certain stage, later and different than the earlier stages of Mongolian transformation. This process may be of course related to the introduced procapitalist projects in the country, that vividly mushroomed there since the 90s (e.g. see: Munkherdene 2018), but first of all it is a quite generic socioeconomic activity, which is still quite hard to grasp. That means it is not fully understandable in terms of "modernization" or "urbanisation of the steppe", nor 
it is restricted to a sort of persistency of the earlier social form i.e. the nomadic system of exchange of goods and labour, both material and spiritual. It is rather a new form of post-pastoral socioeconomic organization that has vividly developed and could be understood in terms of sociality, competition, and finally as a form of solidarity.

\section{"From nomads to riches": Sedentarization and the educational race}

These reactions are first of all the new patterns of sedentarization and mobility coming from pastoral self-organisation, and still bringing about the redevelopment of this pastoral legacy. Moreover, the notion of urbanisation as making modernisation first of all social, and prior to technical in terms of economic development, may be extremely useful in understanding the multiplicious process of economic and in fact the political way of building the virtue of "keeping things together", "keeping people together" - goods, relations, bonds, kin networks, etc., as it was in labour exchange in negdel brigades. So what I would like to particularly focus on is the fact that Torghut businessmen used their former pastoral and family-based networks and collectives broadly in order to shape their new businesses. In other words, their activities are rooted in historical phenomena, namely in the socialist-driven system of exchanging work, goods, animals or sharing pastures (see: Sneath 2003, 2006).

When I encountered a new, young generation of herders, they were basically a group of Torghuts, children of herders, mostly from the Beilijn group (coming from the still used former Manchu administration group divisions), who, after finishing school, started trading on the border with China, importing goods from Russia, establishing stores, and warehouses. However, in this mode of business, everything takes place somewhere on a level that is difficult to notice at first. People close to each other: family, friends, brothers $(a k h)$, and sisters $(e g c h)$ place orders for the purchase of goods in China together. Actually, after the introduction of local border traffic passports, China became the leading destination, for both trading and a sort of holidaymaking. Nasaa, a young, highly regarded maths teacher was going with his wife for a few days to Ürümqi in China, where they were to stay in a Mongolian "hotel" and do some shopping for themselves and their family. So he immediately called "his Torghut friends" from Khovog Sair, a same ethnic-Manchu administrative group from across the border, that stayed thereafter establishing a strict border in the 1940s, who throughout the whole week loaded building materials for the Mongolians, arranged everything for them: taxis, a trip to Ürümqi, Mongolian hotel. He said: "on a daily basis, Bulgan taxis are full of friends travelling with packages and carpets to China and returning with various household appliances, consumer electronics, yurt, and house equip- 
ment". In the context of this informal, intra-social, swift and effective exchange of information, a much narrower and closer community of cooperation emerges - it is even the right unit of activities, a group developing in the circle of family and acquaintances. When we spoke with young, rookie salesmen and businessmen, we soon learned that they subjugate the whole art of starting and developing a business to contacts and help from one's family, friends, and they did not perceive it as inappropriate. When a Torghut woman, Tseden, and her husband from the Uvs region first moved to Bulgan, they started to trade together with her brothers, who passed them most of their contacts from the market, lent them money for the purchase of goods and the car. Her brothers trade rice in Ulaanbaatar, and they are the ones who order and pick up the rice from the young couple, who, on the other hand, buy rice in small batches on the market in China, as cheaply as possible: "My husband arranges everything with them. When he fills a lorry - they send him to the City... Now there is no rice, i.e., there is, but it is expensive... now there is no traffic, we do not buy, and for the time being, we are busy with building our house quickly...”. Also, Tulga, when he was making his first steps in business, worked together with his brothers, with a helping hand from 'older brothers' acquaintances and cousins form the Beiliin group. They traded in wool, leather, meat, bought rice and sent it to Ulaanbaatar. Every time we met him on the central square in Bulgan, he was trying to make various deals while driving around it slowly in a Toyota Land Cruiser 80 series, with several partners sitting inside the vehicle at once, along with his brothers (two brothers had left the shepherding and joined him, the remaining sister is a teacher, and brother - a serviceman). Thus Torghut projects are usually joint ventures, based on family ties and close group relations. Brothers cooperate not only while purchasing goods. They also build and renovate business establishments and premises together as a group. Over the third year of my research Nyamaa has built the best hotel with the help of Ganbat, while Davaa, who was also to use his brother's apartment in Ulaanbaatar, where his student-son rents a room, acts as contractor and coordinator. Soon I realised that several brothers also buy large expensive off-road cars, which are then used as needed, for example, to take the whole family to the city, Khovd, or Ulaanbaatar.

No doubt, this transition is becoming increasingly visible, thus evolving into a common, even global knowledge. Mongolia has started to be recognised as a rapidly developing and economically growing country over the last decade, which is particularly clear through the explosion of the international trade and the mining industry. In the press around the globe a series of articles appeared, pointing to the increasing wealth of Mongolian society, or at least the growing fortunes conspicuous in the city, as the Mongols call Ulaanbaatar, such images also appeared in the Polish press, e.g. an article from "Gazeta Wyborcza" From Nomads to Riches (14.08.2012) - photo coverage and interview with photographer Timothy Fadek, in which he points to modern skyscrapers and rich nightlife in this 'cosmopolitan metropolis', while Lucile Chombart de Lauwe in her article Contem- 
porary Mongolia is changing rapidly („Magazyn Gazety Wyborczej”, 29.01.2015) portraits the nomads with plasma tv sets shining bright in modernly furnished yurts. This is the depiction of modernisation put clearly into a journalistic-cumeconomic style and sense, which for many observers is confirmed by skyrocketing GDP between 2010 and 2013, reaching up to several per cents annually (2011 $17.3 \%, 2012$ - 12.3\%, 2013 - 11.6\%), though this growth shot up in 2009 up until 2013 to slow down to $2.3 \%$ in the second half of the decade. However, the Mongolian transformation is also, and maybe first of all, a dramatic process in terms of the social experience of impoverishment, especially in the 1990s. Within a few years, the know-how assistance and subsidies from the Soviet Union were withheld, the centrally controlled pastoral economy collapsed, much equipment and stock were subject to devastation, the work was disorganised in many ways (Sneath 2002, 2003). With time, many families were left with a small number of farm animals, which sometimes was not enough for sustenance and basic needs of household members. Although throughout several subsequent years flocks were quickly rebuilt, families were driven into the scarcity spiral due to the lack of possibility to transport meat, milk and wool, and generally limited mobility (related to the dissolution of negdels, which were quite crucial for the pastoral rhythm of feeding the herds). At the same time, the liberalisation of prices and market, that followed political transformation and the era of the free-market economy resulted in soaring prices of pastoral products, which only deepened the shortages among the herders, and additionally increased the prices of flour and all the products that the shepherds traditionally lack in their diet. Moreover, in the 1990s, the proportion of people living exclusively from farming increased to almost half of all those in the workforce, and even when in the late 1990s the stock population increased by around $20 \%$, these were still herds, whose meat, wool and skins could not be sold, transported to the City (Khot) and, later on, exported abroad, to China (Sneath 2003: 442). In subsequent years - in the first decade of the $21^{\text {st }}$ century - the situation of herders was still difficult, though finally export started to grow slowly, as did copper and gold production and after a short-lived crisis of 2008-2010 a period of intense growth began, reaching up to several per cents annually (2011-2014), with dynamically growing export to China (China being the most important market - it receives $90 \%$ of goods exported from Mongolia). Finally, that was also the time in which statistical data showed a significant reduction in poverty coverage (38.8\% of the population lived below the poverty line in 2010 , while in 2014 only $21.6 \%$ ), life expectancy has also constantly grown. Small and medium-sized business has been expanding, often organising its production and services around big industrial, and infrastructural enterprises, through joining their contracts as subcontractors (Chuluunbat, Empson 2018; see also: Bumochir, Plueckhahn 2018; Ichinkhorloo 2018).

Local forms of development amongst the Torghuts and Bulgan residents in Bulgan itself and its 'extensions' to the city, or to the Chinese border (or nearby 
towns of the Chinese Xinjiang region, including its capital Ürümqi with the population of two million) are therefore in various ways, even at the most general level, anchored in this context and relate to the changes that are only remotely reflected by macroeconomic indicators or registered statistical and demographic data. And although Bulgan 'got dark' in the 1990s, as the local power station (electricity plant) was gradually dismantled and sold out as scrap, later on, in 2010, the authorities of the soum started to buy electricity from China: as a result, first the centre lit up, and then the rest of the settlement followed. For a few years, there has also been a cell phone range, which is very important to the residents - GPS masts reach deep into the most famous valleys (in the mountain passes, not far from the northern summer pasture of Indert, the shepherds climb high peaks, where the range is said to be good, and toss their telephones high up, hence trying to send text messages; at night, on the road leading from the desert to Bulgan, we saw young people tossing phones with screens glowing in the dark). Thus, especially over the last decade, the areas on the outskirts of the centre are also beginning to fill and continue to grow, people "want to be in the centre", "everyone wants to be close, there are schools, everything is here". "There is electricity, Bulgan is growing, everyone wants to live here" (Süchee's neighbours). In this mood pastoral families, camping in the Bulgan area, more and more often move to the centre of the town-settlement, first of all, I have been told, so that children can go to school. In this way, people from western aimags and neighbouring soums also migrate here. Bulgan attracts them because, as they say, "everything is here". In more extended conversations, they mainly talk about the schools and the border, the stream of goods flowing to China and back, and about the big marketplace, Takashiken, which I just across the border.

Accompanied by spontaneous, sometimes even 'violent' fencing and land acquisition, Bulgan is growing, and new residents settle here, the number of children in kindergartens, schools, and dormitories increases. At the same time, Bulgan continues to have a settlement structure - there are mainly one-story houses made of hand-made clay bricks, or cheap Chinese blocks, heated with tin stoves for wood, argal, and coal; this town-like settlements take up more and more space, and expand in almost all directions, especially to the west, to the south, along the Bajan sudal canal, and to the east and northeast (towards the airport, where the best land is and where the local government plans to continue to loan the area to some investments). However, what is really important here is the fact that herders began in the recent decade to plan their nomadic activities in such a way that they can best accommodate their children in their families and, above all, take care of their education, enabling further careers. Thus, on the one hand, the longestablished system of cyclical, long grazings and fast-moving from one pasture camp to another, which has been developed in the times of negdels and certainly before, in the pre-revolutionary period, has been somehow maintained in this way. But then it started to be readopted to other activities, such as doing business, 
trading, but also, and sometimes first of all, by finding possibilities take a sort of "educational race" of contemporary Mongolia, i.e. widespread migrating to soums, and aimag centres in search of good schools for children, and possibilities of further studying at the universities, usually in cities, in this case Ulaanbaatar, and often also abroad, most typically in Japan, South Korea, Kalmykia (especially Torghuts), and sometimes in Australia. ${ }^{2}$ Thus, the balance of the population of Bulgan remains relatively constant, because at the same time, for the past several years there has been an intensive migration from the pasturelands, to the soum centre and, outside, to the City (Khot), and abroad.

Hereby, it seems to be a sort of quite essential processes of rearranging the social sphere according to new pressures and challenges. In the completely new situation of moving to the centres of soum, aimag, or the country capital, and in taking part in an "educational race" both in the country and abroad, that is now faced by these former herders' families, once workers and specialists in collective farms, now move to the centres and leave their flocks away to their relatives or hire other pastoral families. Thus, my argument is that in the (social) interior of Mongolia we may follow comprehensible ways of rebuilding, reinventing and recreating the social glue that is profoundly related to this new process of urbanisation, and town- or city-migration processes, in the sense of making this social world anew. As it turned out, in this context the very specific, but potentially crucial sources of new ways of exchange emerged, closely linked with the former pastoral forms of collaboration, the "urbanised steppe" as it was called by Markowska, thus creating a sort of thrifty management, and day-to-day solidarity among peers in trade, and in regard to the whole "educational race" their children take part in.

\section{Collective business, thrifty business: "brothering" $(a k h \text { düüsekh })^{3}$}

In my research, it soon turned out that Torghut businessmen used their former pastoral, negdel-like social skills of networking extensively in order to shape their

2 The Torghut, by celebrating their nutag in a way recreate and reconstruct their ethnic identity, also worldwide, as for instance in the case the Jangar naadam, a ceremony and festival associated with the staging of an Oirat epic in the Torgon Nutag Park in Bulgan which was in 2015. It was jointly organized by two associations, Torghut Heritage Association and the Bulgan nutag-committee, and gathered hundreds distinguished Torghuts from abroad, e.g. from Xinjiang, Kalmykia, US and Australia.

3 The description and the idea of 'social thriftiness' among the Torghut was originally developed and described in detail elsewhere, namely in my contribution to the forthcoming book 'Thrift and its Paradoxes: From Domestic to Political Economy', edited by Catherine Alexander and Daniel Sosna (forthcoming, Berghahn Books) and entitled 'Generous Thrift: Post-Pastoral Cooperation and Fortune-Making among the Torghut of Mongolia'. 
new businesses. In other words, their activities were rooted in historical phenomena, namely in a complicated pastoral and then the socialist-driven system of sharing pastures, and exchanging labour, accelerated by their work in collective farms, and thus, according to Markowska, being 'urbanised' (in regard to the social meaning of the term). This was related to the very specific way of organising informal connections and entanglements between herders and local administration in Mongolia (see e.g.: Sneath 2006). The people I met were mostly a new, young generation of sons and daughters of this kind of herders and employees of stateowned cooperatives (negdels). As I mentioned, they were a group of Torghuts, mostly from the Beilijn group, the quasi-lineage based on former Manchu administration divisions, who after finishing schools in the soum and started trading on the border. After some time they built a 5-story block of flats in Ulaanbaatar with apartments, offices, shops and restaurants, which has become a meeting point for the Bulgans coming to the capital, known as Torguud Town.

I entered Torguud Town in the autumn of 2014, with my Torghut-friend, 22 -year-old Bold. The system of sharing goods clearly shaped a very specific environment. When we arrived, after a two-day road trip from Bulgan, before he even managed to leave the car, brothers from the dorm suddenly appeared, took mine and my Togrhut mate's backpacks, bags, and parcels off our shoulders and carried everything to an apartment on the $5^{\text {th }}$ floor. When we came down, Bold greeted everyone with much familiarity, addressing everyone auntie - sister (egch) or brother ( $a k h)$, as well as younger brother or sister (dü̈̈). Kins, siblings, Bulganmates, worked together there, and usually, within inner groups of siblings, or often schoolmates, shared equipment, cars, and looked after each other's premises. Basically, this is the place where Bulgans stay when they come to Ulaanbaatar, this is where they organise goods for sale to China, and the most thriving businessmen help the young to settle down there; they also host people from Bulgan and organised medical care. The social network was dense. Bold's uncle, Galsan, ran a shop he leased from his brother, who had built the tower block and had his company on the first floor, while his brother had an office next door, where his wife worked. In the evening, Galsan, one of the creators of the Torguud Town, supervised his shop, which he leased from his brother. Apartments were made available to relatives from Bulgan, whereas offices and companies occupied two central floors located below. It is where members of the same groups worked: the wife of one of the most successful vendors-businessmen, Batnasan, worked in a company run by Galsan, located right next door.

In that way, this place brought together Bulgan circles in Ulaanbaatar. It was where a sort of social "internal circulation" of goods and relations come into focus. In the apartment blocks around the Torguud Town building, there were Torghut services, businesses, hairdressers, pawnshops, shops, canteens, and bars with pool tables. Several young Torghut women, all of them Bold's cousins or acquaintances, worked in a guanz (food bar) located in the central part of the building, 
and also, about five young Torghut women worked at the cash register in a small shop, run by Galsan. At the same time in these dorm apartments live five to six people, groups of brothers and sisters from Bulgan, who studied in Ulaanbaatar (there is also a more "secret" passage in the back, leading from canteen to the office and residential part, which Bold and I used freely and where Torghut families, construction workers, and their children live in student dormitories). Bold lived in such a dormitory, Tsogtt's apartment, along with his two brothers, his son and a cousin. Downstairs was another dorm, "brothers" from Bulgan, and again private apartments occupied by the co-owner, i.e. Tsogt's's relatives. They all slept on the floor, on mats, and periodically exchanged places in their flats. When I lived with them and with the 'brothers' they slept on the floor of the largest room every day someone slept somewhere else, someone came back, the nurse "vacated" her room, then came back for some time. This technique of swap was thus a form of trained togetherness and the specific art of replacing one with another. In this manner a pastoral form of ownership, which originated in a kind of thrifty navigation of property, goods, and investments especially counts here. A pastoral form of ownership, which originated in the former pastoral land use (Empson 2014, 2018; Endicott 2012; Plueckhahn 2019, 2020; Sneath 2003), makes possessions collective and only temporarily assigned to a group, family, or a person. ${ }^{4}$ Generally speaking, these forms are drawn from a kind of family-based informal ties, of a socio-technical, informal system of common use of goods and land (see: Sneath 2003), but also consist of an interplay of interests, and leave some room for extortions, shifting borders, even the quiet seizure of territory. But, to put it differently, this interplay is directly related to the complex way in which such uses are organised around collective, and spiritual resources managed thriftily. Therefore, these big, new off-road vehicles (Toyota Land Cruisers) in which they drove me from the Bulgan soum and the city to various places, were almost always collective property, registered by one of the brothers, both for prestige and practical reasons usually several brothers had purchased big expensive cars.

These cars, of course, enabled fast transportation to Bulgan for instance, which was crucial for the Torghut business and thus Gantbat, one of the best vendors, changed to a new car twice during our five-year fieldwork, despite living in a modest, one-story, brick house in Bulgan. This example also shows why, when they run their businesses, they usually assume that it simultaneously affects several people. The thrifty system of collectively managing ownership here, plus a certain flexibility, owes a lot to a complicated system of land use, which can be negotiated or delicately "shifted" between neighbouring herders, that use distinct pastures in each season (Potkański, Szynkiewicz 1993: 44-46). Thus, in the case of Bulgans, we find a sort of collective management, associated with fast-growing business-

4 This is a form of temporal lease and land tenure (see: Endicott 2012; more on 'temporary possession', ezemshil, in Mongolia, see: Empson 2018; Plueckhahn 2019, 2020) lasting for years or decades, and regulated by the local government. 
es and a wide range of activities, which is also related to ceaseless susceptibility to possible failure (that also happened both in Ulaanbaatar and in Bulgan over my stay). However, since this is a family- or schoolmate-based centre of activity, the risk is different and sometimes even higher, but it is not only still taken into account in that collective entrepreneurship, but also was managed through the above-mentioned easy-exchange, a virtue of swap one with another. Thus, the considerable degree of business diversification among e.g. siblings goes hand in hand here with risk-taking, which can be easier to comprehend precisely when the activity is collective and based on the virtue of interchangeability. In my view, however, pointing at kinship patterns, still present, but still in transition, pointing at the kinship structure based on patrilinear and patrilocal principle, the durability of lineages, houses (elkens), and former Manchu administration groups, with a more elaborated kinship structure (as Szynkiewicz wrote about family in Mongolia, Szynkiewicz 1981) would also be to omit a little, a certain incredibly dynamic, "functional" and, finally, the human dimension of the world of the Bulgan Torghuts. Pursuing this very doctrine, I would like to follow in the footsteps of Tim Ingold, who has recently taken specific measures in this spirit. He pointed to a particular verbal, functional character of defining what is human and social, by creating a neologism "to human". In To Human is a Verb (2014), he wrote and demonstrated that it is a constant struggle to exert a particular "human" pattern on reality, with all its susceptibility to fragility, instability, dependence on what is external and a bit random. In doing so, he referred to the image of man as an animal hominificans, created in the $13^{\text {th }}$ century by the poet and mystic Ramon Llull from Mallorca; his translators emphasised the meaning of the verb "to humanify", and not "to humanise", so actually "to humanify" as continuous, skilful acting and coping. Similarly, I would like to show that on a social, economic and even spiritual level, Torghut groups of brothers and sisters from the Bulgan soum act through their relationships with brothers and sisters, through networks and through the worlds in which all that happens and how it happens is understood, so to speak, in a multicentric way, that is, in a diverse but initially united group. I would, therefore, use a neologism here: verbs "to brother" and "to sister" to render the way the Torghuts operate, self-organise, develop their business, swap in different situations.

This "brothering" and "sistering", in which Mongols use an idiom here, meaning literally "brothering" ( $a k h$ düüsekh), is thus a form of collective entrepreneurship, in which a particular flow and "turn" take place, also gives a sense of security and a moment of acting that is good, effective, and proper. As Oyungerel's interlocutor (Oyungerel 2013), an entrepreneur from Ulaanbaatar, 45-year-old Ariun has said:

to be honest, I don't have any money saved, you usually borrow it here, you give it back there, you borrow it from one, you give it to the other, and somehow the business goes on. It is essential to have someone from whom and to whom. Money is not important, but friends are [...]. My 
nephew, when he grew up, went to Japan, had a manual job, but he did not feel right there. We felt sorry for him, so we paid with our money for his college in the States. He is doing great over there. He works at McDonald's and studies. We go to the USA to get the goods every six months, and he helps us get the goods. Sometimes we visit our sister in Japan, and we manage. I always had the impression that the more we give, the more we get in return, so it is worth having someone to give and from whom to take.

Except for running a family business in this way, also a kind of navigation of property, goods, and investments counts here. Such activities are in place when one thinks more about the effects they bring, even without crossing a specific horizon of events, a little "at random", but one thinks about the economic dimension as a whole, but definitely, family leaders, "the right" people, "older brothers", "older uncles" are the ones who manage investments and business. Flows and wealth sharing are very characteristic here. As a rule, wealth is mostly originally shared; it is a form of temporary, prestigious, cost-incurring possession, assigned to a specific person, honoured with privileges (it can be the oldest brother or the most thriving entrepreneur, but also newlyweds at a Torghut wedding). It can also result from the contributions of many people. It is, therefore, a form of transformed, and extended ezemshil, extended "temporary possession" (as described extensively in Empson's and Plueckhahn's works, see: Empson 2014, 2018; Plueckhahn 2019, 2020).

This story makes us well aware of how wealth, prestige, and community are collectively managed and reveals the temporary use of goods. It shows well why Torghuts, when they run their businesses, usually assume that it simultaneously affects several people. Therefore, the big, new off-road vehicles by which they drove me from the Bulgan soum and the City (Khot) to various places, were almost always a collective property, registered with one of the brothers, both for prestige and practical reasons. They allowed for fast transportation which was crucial for the Torghut business - thus they were essential. As were flats in the Torguud Town, enormous herds, counting thousands of animals, which were a rather unnecessary addition to business (they provided a retirement pension for parents, meat for the family, etc.), goods, trucks with rice. To a certain extent, we can say about the transition of property, certain flexibility, as in the case of land rights, which can be 'shifted' by neighbours, or rights to nomadic camping, which can be "shifted" by herders (Potkański, Szynkiewicz 1993). In the context of postsocialist Mongolia, it is also something that Morten Pedersen and Lars Højer (2008) call "fuzzy property", borrowing the notion form Katherine Verdery's works; they point to a group of brothers in Ulaanbaatar where the oldest working brother had the most influential position and determined the possession of resources, thus concentrating ownership (housing and land), although it was constantly negotiated and reinterpreted with his family, especially with his three unemployed brothers. Such property, in their words, "is in a constant process of negotiation where moral codes, traditional values, kinship obligations, liberal notions of ownership, coincidences, and security-concerns all interven" (Pedersen, Højer 2008: 13). 
However, they pointed to the fate of a group of brothers with the oldest working brother having the most influential position, although it also affected his three brothers, who basically drank and lost what they earned.

In the case of Bulgans, on the other hand, we deal with collective, effective management, associated with fast-growing fortunes and a wide range of activity, despite ceaseless susceptibility to possible failure. However, since this is a common, family, and multi-centre activity, the risk is different and much higher. Many Bulgan businessmen boldly and eagerly start various enterprises, open and close guanzs, restaurants, shops, change their location, launch bus lines City-Bulgan, then close them and sell the bus to buy a truck, etc. Galaa's second son, after serving in the military signal corps opened an Internet Cafe in Bulgan, visited continuously by his cousins and sometimes ran by his father. Galaa was very proud of his son and his new business, but a year later there was no trace of the café there; his son worked in a military unit, Galaa was a truck driver, and they were doing rather well, as they said. At the same time, Ganbat proudly showed us his sea buckthorn plantations situated in the middle of the steppe north of Bulgan. He showed us around the rows of trees for a long time. Some of his family members worked there, but in the last year of our meetings, he said that they had to give it up as the plantation was gradually becoming less important for him, and they did not do much there any longer. The same happened with a little flour factory, which used to be a serious business, as it supplied goods to the whole soum and gave employment to about 20 people. It was even depicted in a folder documenting the development of the soum (The Bulgan Soum Development Plan for 2009-2020). In the last year, it turned out, however, that the factory is not profitable, and Chinese do not want to buy flour for their noodles. At the same time, the businesses of Ganbat, Nyamaa and other brothers operated at full speed. They built the most luxurious hotel with a restaurant, expensive store (they had no customers and the women working there said they would certainly close the business for the winter) and a small department store (with a pharmacy, supermarket, and modern dental office). Especially at this point, I would like to say that by making this use of the notion of "thrifty businesses" as particular anthropological term, one may build a strong heuristic tool for understanding the processes of current and powerful transformations present for instance in the depicted case. Thus, I am aiming to open a possible understanding of thrift as a key term, drawing on earlier (Gudeman, Rivera 1990) and quite recent dabates on this notion (Alexander, Sosna forthcoming; see also: Gudeman, Hann 2018), which may initiate anthropological interpretation and embody the riddle of the rapid, impetuous process of the Mongolian postsocialist transformation, and its further developments. To put it simply: I believe that this transformed use of the notion makes it possible to interpret and understand the impetuous complex mechanisms of social cooperation that came with the impact of new political/economic conditions experienced by the Mongols after the 90 s. However, as has been mentioned, it is not to say that 
the process of transition is completed or, as Manduhai Buyandelgeriyn (2008) noticed, may be easily rendered as a sort of "natural" process, understood in a slightly evolutionist, or even unilinear way. Therefore, of particular interest here is the entire spectrum of behaviours and organisational forms based on family-based and negdel-like connections. On the one hand, we deal with the informal use of what is common (but which leaves some room for extortions and quiet seizure of goods), but, on the other hand, it is related to a complex manner of the use as organised around collective resources, managed in a particularly thrifty way, i.e. kept together, held together, supported, protected, but at the same time accumulated and used with a sort of generosity. However, what I really like to point at here, is the argument that in "urbanisation of the steppe" we can find the idea of building and developing first of all the social within the process of modernisation and change, which probably might just have happened in the moved and transfigured pastoralists' soums.

\section{Conclusion: “Urbanisation” as a technology of solidarity}

Sławoj Szynkiewicz, Markowska’s close collaborator (see e.g.: Markowska, Szynkiewicz 1969), in the texts such as Mongolia's Nomads Build a New Society Again (1993) showed that these transformations might be even considered as in fact cyclical, because of the necessity to adapt to natural disasters of $z u d s$, with which herders have been familiar for several hundred years. Cooperation and adequate numbers of herds and the whole mentioned 'socio-technical system' were thus related to the ability to respond to $z u d s$ and to really harsh weather conditions coming in winter and early spring. Thus, on the one hand, the long-established system of cyclical, long grazings and fast transfer from one camp to another, which has been developed in the last century, was still being maintained over the time of negdelization. On the other hand, however, it has also now transposed to completely different activities, such as doing business in China, in the capital city, or in taking part in the "educational race". Moreover, even the remaining shepherds on the steppes are beginning to plan their nomadic activities in such a way that they can best accommodate their children in their families and, above all, take care of their education, enabling further careers.

Thus, the process is basically about keeping very intimate relations with each other, but also this is also about competition and rivalry, and sometimes even violent hierarchical games. However, this is still a depiction of a reorganisation of the society, but more "on their own terms", and still linked to pastoralism and its social skills. What is more, this may be conceived as a sort of "technology of solidarity", thus requesting a deeper translation from Mongolian idiomatic practices of mutual aid and from operating in local groups (e.g. like in the institution of idesh: Mongols provide food for their families living in the city of $\mathrm{UB}$, and receive 
favours in return). Moreover, this is quite characteristic that this very intimate relation acquired through the exchange and swap has created many informal activisms (often sought and desired as "civil society", the relevant literature: see e.g.: Bumochir 2018) usually related to the nutag, the local pasteurs, and the soum, considered as "local" or "little" homeland, and finally - to the so-called nutagism, which is another dimension of this activism. Still, when the businesses, groups, cars, and housing are "kept together", it seems to resemble a certain mastery of social self-sufficiency, that was created on many levels within the group of khotail (holding the animals in the proper place, following the capacity of pastures, etc.).

However, at the same time, there is a stark contrast to these kinds of collective self-sufficiency, conceptualised as "house economies", as Gudeman and Hann (2018: 13) put it, with "modern corporations" depending on "specialisation, optimisation, and exchange". But in fact here the relation between thrifty house economies (the thrifty Torghut businesses) and market economy may be, to some extent, followed rather as a certain continuum. The moment of an "economic transfiguration" leading to modern economics, as it was re-examined by Stephen Gudeman, is particularly useful here: the "house economy" can be understood as the broader model economising a certain socioeconomic unit. A striking paradox appears then, as at some point the house economy, through the art of "economising", the post-pastoral "urbanising" gives way to capital accumulation and enables something that could be caught by the notion of economic liquidity. A sort of a shift comes from here, a shift from house exchange, self-sufficiency, and the increased social swap to the market economy. The paradox is then the riddle of the deeper logic of the above (quite surprising) transfigurations as it opens the latent modes of acting with a form of imminent solidarity reactions. However, the problem is that the term "solidarity" is still of very broad meaning and may be stretched, e.g. down in Afghan valleys, from kinships networking in providing and sharing remittances among siblings to violent rivalry among patrilateral kins (see a detailed view on that: Monsutti 2004: 221-226). Basically, it is rather not a precise analytical tool, but, according to Theodoros Rakopolous 'an idea inspiring people in contexts of everyday life in crisis' (Rakopolous 2016: 143). But solidarity practices, as he wrote in regard to Greeks' response to the financial crisis they faced in 2009, were in this sense also akin to "socio-technical systems", rooted in "sociocultural history of its own". What is more, they were originated in rural contexts and then transpired, along with kinship ties-like open system, to urban centres, however, as points out, citing Roger Just, "urban and rural life are

5 The local homeland, the nutag, has a broad meaning in contemporary Mongolia (Sneath 2010, 2014): the groups supporting their local homelands, pastures and settlements, such as nutag-committees, have been functioning in Mongolia for several years, they have been lobbying parliament on behalf of their hometowns and settlements thus creating a broad phenomenon of nutagism in Mongolia (Shagdar 2015; Sneath 2010, 2014; Bumochir 2019; Stolpe, Erdene-Ochir 2021), and often speak of managing the spiritual qualities of the locality, the 'living' or 'animated' landscape. 
so intertwined that the one cannot be understood without reference to the other" (cited from: Rakopolous 2016: 144).

In the described case the forces of "urbanisation" are still rooted in mobility, constant swap and a "technology of solidarity", and thus directly related to holding them, and at the same time distribution within, and in this sense one could say we also follow in this regard the classical work done on vernacular economics (see e.g. subsistence farming among Russian peasants-Soviet villagers, conducted by Alexander Chayanov, Chayanov 1966). In this way I have focused on various forms of cooperation and self-organisation that appeared among a new generation of the Torghuts, sons and daughters of the herders in Bulgan soum in western Mongolia, now developing their own businesses in Ulaanbaatar and operating according to their post-pastoral idioms. However, what I found particularly interesting here is the situation in which their knowledge about how to act socially demonstrates itself in the activities "fulfilling" social actors, filling their lives with the modernising process as first of all the domain of the social (as prior to the technical), which is somehow well-known to them, but requires at the same time flair, effort, adeptness and risk-taking. I drew on how these groups developed an informal system of collaboration in the urban environment, thus creating their post-pastoral ways of navigating collectiveness, as it is in the depicted "social hub" of Torguud, established by the Bulgans in the capital. In this way, new trajectories of these pastoral and post-pastoral communities were triggered, along with new social patterns, increased mobility, "urbanisation of the steppe", and then relevantly "urbanisation of the city", along with the gradual retreat from pastoral occupations in postransitional Mongolia.

\section{Acknowledgements}

I wish to thank the editors, Ivan Peshkov and Zbigniew Szmyt, for inviting me to contribute to this collection of texts. I thank also the reviewers for their thoughtful hints and remarks. Besides, I am grateful to my dear colleague, Oyungerel Tangad, for her support, and for our work together in Mongolia. My warmest appreciation goes also to the Torghuts for their great hospitality, openness, and friendship. Finally I wish to thank also Catherine Alexander and Daniel Sosna, the editors of the forthcoming book Thrift and its Paradoxes: From Domestic to Political Economy (Berghahn Books), as the idea of "social thriftiness" among the Torghut was initially developed during our collaboration and enabled me to build the argument presented in the article published here. 


\section{Bibliography}

Alexander C., Sosna D. (eds.)

(forthcoming) Thrift and its Paradoxes: From Domestic to Political Economy, Oxford.

Bumochir D.

2018 Mongolia in: A. Ogawa (ed.), The Routledge Handbook in of Civil Society in Asia, London.

2019 Nationalist Sentiments Obscured by 'Pejorative Labels': Birthplace, Homeland and Mobilisation against Mining in Mongolia, "Inner Asia”, vol. 21 (2), pp. 162-179.

Bumochir D., Plueckhahn R.

2018 Capitalism in Mongolia - Ideology, Practice, and Ambiguity, "Central Asia Survey", Special Issue: Capitalism in Mongolia, vol. 37 (3), pp. 341-356.

Buyandelgeriyn M.

2008 Post-Post-Transition Theories: Walking on Multiple Paths, "Annual Review of Anthropology", vol. 37 (1), pp. 235-250.

Chayanov A.

1966 The Theory of Peasnat Economy, Homewood, Illinois.

Chombart de Lauwe, L.

2015 Wspótczesna Mongolia gwałtownie się zmienia. Fotografie, „Gazeta Wyborcza”, 29.01.2015.

Chuluunbat N., Empson R.

2018 Networks and the Negotiation of Risk: Making Business Deals and People among Mongolian Small and Medium Businesses, "Central Asia Survey", Special Issue: Capitalism in Mongolia, vol. 37 (3), pp. 419-437.

Empson R.

2012 The Danger of Excess. Accumulating and Dispersing Fortune in Mongolia, "Social Analysis", vol. 1 (56), pp. 1-12.

2014 An Economy of Temporary Possession, Malinowski Memorial Lecture, 2014 [audio-record].

2018 Claiming Resources, Honouring Debts: The Cosmoeconomics of Mongolia's Mineral Economy, "Ethnos", vol. 84 (2), pp. 263-282.

2020 Life in the Gap: Subjective Lives and Economic Transformations in Mongolia, London. Endicott E.

2012 A History of Land Use in Mongolia. The Thirteenth century to the Present, New York.

Fadek T., Kenig K.

2012 Z nomadów bogacze. Z Timothym Fadekiem rozmawia Kinga Kenig, „Gazeta Wyborcza. Duży Format", 14.08.2012.

Gudeman S., Hann Ch. (eds.)

2018 Oikos and Market: Explorations in Self-Sufficiency After Socialism, Oxford.

Gudeman S., Rivera A.

1990 Conversations in Colombia. The Domestic Economy in Life and Text, Cambridge.

Halemba A.

2011 Three Houses of Culture in Kosh Agach: Accounting for Culture work in a Changing Political Setting in: O. Habeck, B. Donahoe (eds.), Reconstructing the House of Culture: Community, Self and the Makings of Culture in Russia and Beyond, Oxford and New York, pp. 97-116. 
Humphrey C.

2012 Favors and "Normal Heroes". The Case of Postsocialist Higher Education, "HAU: Journal of Ethnographic Theory", vol. 2 (2), pp. 22-41.

Humphrey C., Hürelbaatar U.

2012 Fortune in the Wind. An Impersonal Subjectivity, "Social Analysis", vol. 2 (56), pp. 52-167.

Ichinkhorloo B.

2018 Colaboration for survival in the Age of Market: Diverse Economic Practices in Postsocialist Mongolia, "Central Asia Survey", Special Issue: Capitalism in Mongolia, vol. 37 (3), pp. 386-402.

Ingold. T.

2014 To Human is a Verb in: M.Buchowski, A. Bentkowski (eds.), Colloquia anthropologica: issues in contemporary social anthropology, Poznań.

Leszczyński A.

2013 Skok w nowoczesność. Polityka wzrostu w krajach peryferyjnych 1943-1980, Warszawa.

Markowska D.

1969 Urbanizacja stepu in: W. Dynowski (ed.), Studia mongolskie, Wrocław.

Markowska D., Szynkiewcz S.

1969 Spółdzielnia pasterska. Tradycja i modernizacja in: W. Dynowski (ed.), Studia mongolskie, Wrocław.

Monsutti A.

2004 Cooperation, Remittances and Kinship among the Hazaras, "Iranian Studies", vol. 37 (2), pp. 219-240.

Munkherdene G.

2018 The formation and distribution of procapitalist perspectives in Mongolia, "Central Asian Survey", vol. 37 (3), pp. 372-386.

Oyungerel T.

2013 Scheda po Czyngis Chanie. Demokracja po mongolsku, Warszawa.

2017 Cultural Aspects of Democratization In Mongolia. The Ethical Perspective, "Ethnogia Polona”, vol. 37, pp. 133-144.

Paczkowski A.

2014 Historyk dziejów najnowszych wśród źródeł in: E. Domańska, R. Stobiecki, T. Wiślicz (eds.), Historia - dziś. Teoretyczne problemy wiedzy o przeszłości, Kraków.

Pedersen M., Højer L.

2008 Lost in Transition: Fuzzy Property and Leaky Selves in Ulaanbaatar, "Ethnos", vol. 73 (1), pp. 73-96.

Pfaffenberger B.

1992 Technology and Social Change, "Annual Review of Anthropology", vol. 21, pp. 491-516.

Plueckhahn R.

2019 Rethinking the Anticommons: Usufruct, Profit, and the Urban, https://culanth. org/fieldsights/rethinking-the-anticommons-usufruct-profit-and-the-urban (access: 29.09.2019).

2020 Shaping Urban Futures in Mongolia: Ulaanbaatar, Dynamic Ownership and Economic Flux, London. 
Potkański T., Szynkiewcz S.

1993 The Social Context of Liberalisation of the Mongolian Pastoral Economy, [Report of Anthropological Fieldwork No. 4.] Warsaw-London-Ulaanbaatar.

Rakopolous T.

2016 Solidarity: the Egalitarian Tensions of a Bridge-concept, “Social Analysis”, vol. 24 (2), pp. $142-151$.

Shagdar T.

2015 Homeland Association and the Production of Informal Power in Mongolia, https:// blogs.ucl.ac.uk/mongolian-economy/2015/11/05/homeland-associations-and-the-production-of-informal-power-in-mongolia/ (access: 14.05.2016).

Sneath D.

2002 Mongolia in the 'Age of Market'. Pastoral Land-use and the Development Discourse in: C. Humphrey, R. Mandel (eds.), Markets and Moralities. Ethnographies of Postsocialism, Oxford-New York.

2003 Land-Use, the Environment and Development in Post-socialist Mongolia, "Oxford Development Studies", vol. 31 (4), pp. 441-459.

2006 Transacting and Enacting: Corruption, Obligation and the Use of Monies in Mongolia, "Ethnos", vol. 71 (1), pp. 89-112.

2010 Political Mobilisation and the Construction of Collective Identity in Mongolia, "Central Asian Survey", vol. 29 (3), pp. 251-269.

2014 Nationalising Civilisational Resources: Sacred Mountains and Cosmopolotical Ritual in Mongolia, "Asian Ethnicity", vol. 15 (4), pp. 458-472.

Stolpe I., Erdene-Ochir T.

2021 Nutag Councils as Post-Socialist Resilience Cultures in Mongolia in: I. Stolpe, J. Nordby (eds.), Horizons of Future in Post-Utopian Mongolia, Berlin, pp. 49-114.

Szynkiewicz S.

1981 Rodzina pasterska $w$ Mongolii, Wrocław.

1993 Mongolia's Nomads Build a New Society Again: Social Structures and Obligations In the Eve of Privatisation, "Nomadic Peoples", vol. 33, pp. 163-172.

Walicki A.

1995 Marxism and the Leap to the Kingdom of Freedom. The Rise and Fall of the Communist Utopia, Stanford.

Yurchak A.

2003 Soviet Hegemony of Form: Everything Was Forever, Until It Was No More, "Comparative Studies in Society and History", vol. 3, pp. 480-510. 